\title{
Looking back, moving forward: Improving the lives of orphans and other children affected by AIDS, Horizons studies 1998 to 2007
}

\author{
Katie D. Schenk \\ Population Council \\ Annie P. Michaelis \\ Tobey C. Nelson \\ Lisanne Brown \\ Ellen Weiss \\ Population Council
}

Follow this and additional works at: https://knowledgecommons.popcouncil.org/departments_sbsr-hiv

Part of the Demography, Population, and Ecology Commons, Family, Life Course, and Society

Commons, International Public Health Commons, and the Medicine and Health Commons

How does access to this work benefit you? Let us know!

\section{Recommended Citation \\ Schenk, Katie D., Annie P. Michaelis, Tobey C. Nelson, Lisanne Brown, and Ellen Weiss. 2010. "Looking back, moving forward: Improving the lives of orphans and other children affected by AIDS, Horizons studies 1998 to 2007," Horizons Synthesis Background Papers. Washington, DC: Population Council. Version of record: https://doi.org/10.1177/003335491012500223}




\section{LOOKING BACK, MOVING ForWARd}

IMPROVING THE LIVES OF

Orphans and Other Children

\section{AfFECTED by AIDS}

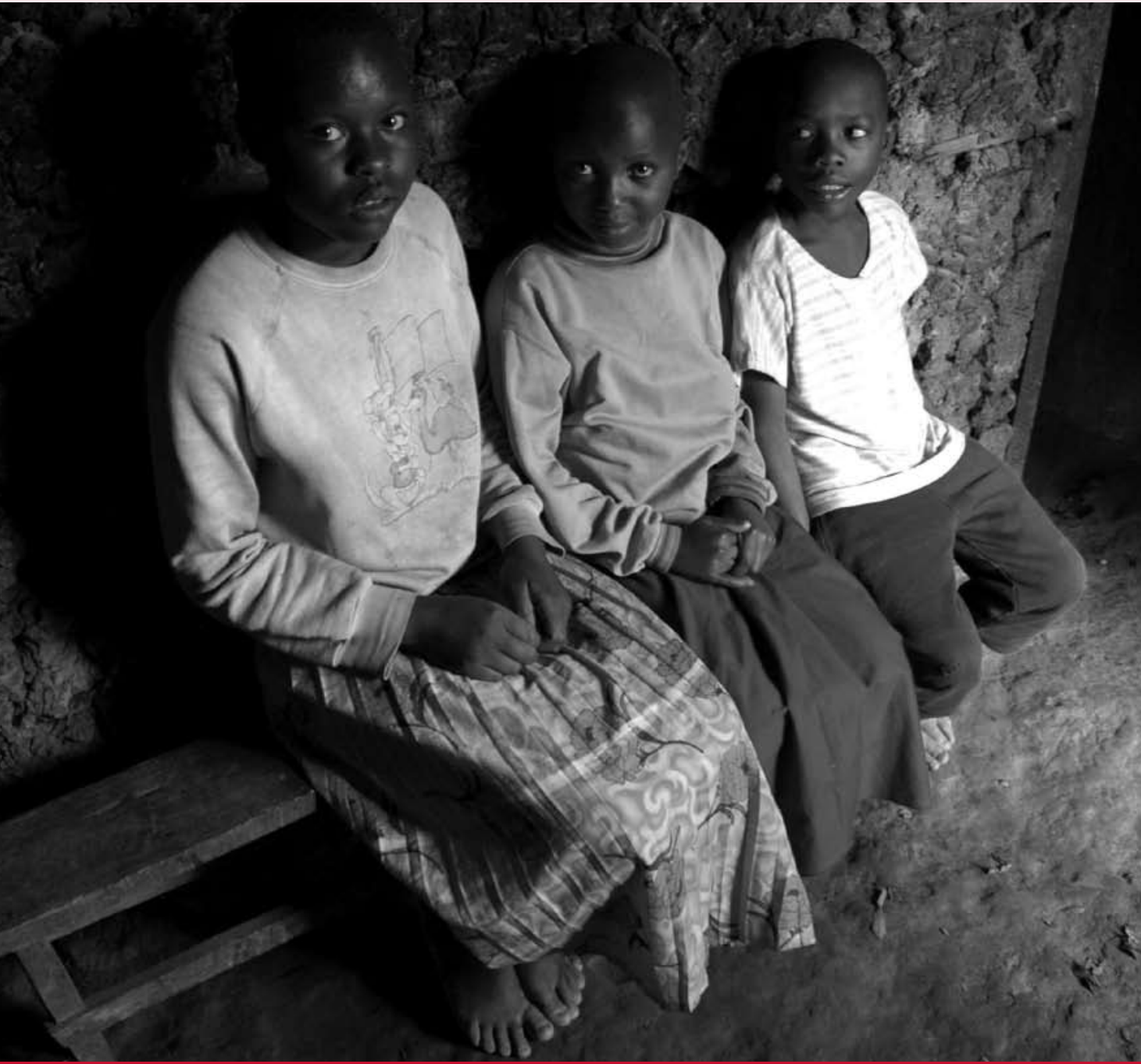

HORIZONs StUdies 1998 TO 2007 


\section{Hgrizons}

In 1997, the Population Council initiated the Horizons Program—a decade-long USAID-funded collaboration with the Family Health International, the International HIV/AIDS Alliance, Johns Hopkins University, International Center for Research on Women, PATH, Tulane University, and the University of Alabama at Birmingham—designing, implementing, evaluating, and expanding innovative strategies for HIV prevention and care.

Horizons developed and tested ways to optimize HIV prevention, care, and treatment programs; worked to reduce stigma and improve gender-biased behaviors; and greatly expanded knowledge about the best ways to support, protect, and treat children affected by HIV and AIDS. In all its projects, Horizons strengthened the capacity of local institutions by providing support and training to colleagues.

This series of synthesis papers presents lessons learned and best practices on six key topics that Horizons investigated: HIV-related stigma, access to Antiretroviral Therapy, men who have sex with men, orphans and vulnerable children, HIV and gender, and prevention of mother-to-child transmission of HIV. 


\section{Improving the Lives of ORPhANS AND Other Children Affected by AlDS}

In 1997, the Horizons Program began studying the care and support of orphans and vulnerable children (OVC) in sub-Saharan Africa, focusing on large gaps in our understanding of how AIDS affects children and how caregivers were coping. The research showed that children understandably suffer considerable distress at the illness and death of their parents, but that succession planning, linking children with community resources, participation in mentorship programs, and other programs can significantly improve well-being. Horizons researchers developed tools for assessing the well-being of children affected by HIV and outlined key ethical guidelines for conducting research with children. The design, implementation, and evaluation of community-based OVC interventions continues to be a key gap in the evidence base.

\section{Introduction}

Studies conducted in sub-Saharan Africa in the early 1990s documented a rise in the number of orphans and the breakdown of protective social networks and supports for them as a result of the AIDS epidemic [1,2]. A landmark study in 1997, revealed that globally the number of orphans was increasing and that experience responding to orphaning as a social problem was limited [3].

As an initial response, some international and local agencies established orphanages. Child advocates soon criticized this approach as inefficient and unsustainable, undermining traditional models of family and community care, and creating adverse psychological and social effects among children and families [4, 5]. At the same time, many program imple- menters began to recognize what communities had long noted, that children whose parents had died of AIDS were not the only children affected by the epidemic. The operational term "orphans and vulnerable children" or OVC was thus coined to include not only orphaned children but also children considered vulnerable to shocks (such as living with a parent who is chronically ill) that endangered their health and well-being.

As the numbers of vulnerable children steadily grew with the increasing numbers of adults infected with HIV, so did the demand for greater knowledge about the lives and needs of OVC, their families, and their caregivers. The UN's Millennium Development Goals, the U.S. President's Emergency Plan for AIDS Relief (PEPFAR), and other important health and development initiatives incorporated 
OVC programming into their platforms. Yet little research had been done and few tools were available to measure the psychosocial manifestations of vulnerability and to evaluate approaches to reduce associated negative outcomes. There were limited data available to answer the key questions of what works in providing care and support to children and families, and how best to offer it.

Against this backdrop, in 1997 the Horizons Program began an ambitious agenda of operations research, which included a focus on the care and support of orphans and other children rendered vulnerable by HIV and AIDS in subSaharan Africa. These studies (Appendix) were conducted in collaboration with numerous local and international research and program implementation partners in several countries.

This paper summarizes the key contributions of the Horizons research portfolio among orphans and vulnerable children in describing the impacts of the epidemic on children, assessing the effectiveness of community-based interventions, identifying insights from program implementation, and improving methods for researching OVC programs. Based on this information, this paper concludes with recommendations for future programming and research aimed at mitigating the negative effects of AIDS on children, families, and communities. develop interventions to address the most serious problems.

Prior to the Horizons Program, OVC research had emphasized material deprivation. Horizons research gave equal attention to psychosocial distress experienced by children affected by AIDS. In a study in Rwanda, 55 percent of youth heads of households reported symptoms of clinical depression, and said that their parents' deaths had negatively affected their confidence in other people, the meaning they placed on their own lives, and their religious beliefs. Over one-half reported feeling that life was no longer worth living at least some of the time, and 4 percent had attempted suicide in the two months preceding the survey [6].

In a study in Zimbabwe, vulnerable youth reported experiencing multiple distresses, including stigma, rejection in times of need, and the absence of adults to talk to about relationships and problems (Table 1). More than half reported feelings of worry or stress, irritability, sadness, difficulty concentrating, being overwhelmed, and hopelessness during the past month [7].

Horizons studies identified adult support as an important missing link in the psychosocial well-being of vulnerable children and youth. In the study in Zimbabwe, youth emphasized the need to talk with adults about relationships,

\section{Diagnosing the Problem}

As Horizons began to develop its research agenda, it became clear that there were large gaps in our understanding of how AIDS affects children and how caregivers were coping. Yet this information was critically important to identify which populations to target and
Table 1 Traumatic and stigmatizing psychosocial life experiences among OVC in Bulawayo, Zimbabwe

\begin{tabular}{ll}
\hline $\begin{array}{l}\text { People saying bad things about them or avoiding them because of their } \\
\text { family's situation }\end{array}$ & $\% 2$ \\
$\begin{array}{l}\text { Being rejected, neglected, or abandoned by their relatives when they } \\
\text { needed them }\end{array}$ & 51 \\
Losing the support of their friends when they needed them & 49 \\
Having too much responsibility or work & 37 \\
\hline
\end{tabular}




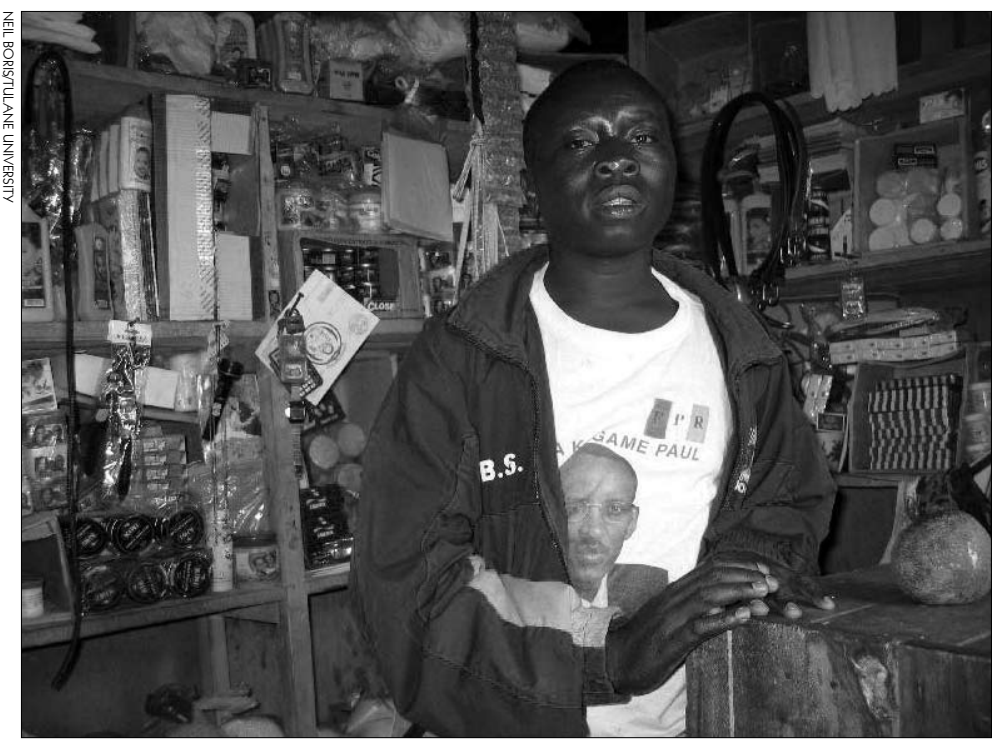

Horizons' research brought new attention to material and psychosocial distress. For example, in a Horizons study in Rwanda, 55 percent of youth heads of households reported symptoms of clinical depression.

but many felt that adults did not acknowledge the challenges young people face in dealing with HIV. The youth felt belittled when trying to discuss romantic relationships [7]. In some cases, family disputes — often about property or other resources - alienated them from the adult relatives to whom they would normally go for advice. Half of the respondents felt that they were not consistently supported by the adults in their lives [7].

Research highlighted the range of health risks and limited access to material and social resources experienced by children who have been orphaned. At three rural sites in South Africa, a Horizons study found that orphans were more likely to leave school than nonorphans and were more likely than their peers to cite financial constraints and sickness as the reason for dropping out [8]. Horizons also documented risky sexual behaviors among orphans in communities in KwaZulu-Natal, South Africa, including a younger age of sexual debut and a higher rate of transactional or survival sex, compared to non-orphans [9].
The death of a parent is not the only driver of vulnerability; parental illness from HIV can instigate such feelings in youth. An important finding documented by Horizons and partners is that children's vulnerability often begins once a parent is diagnosed as HIV-positive or becomes ill. For example, in a Horizons study in Uganda, about a quarter of teens with HIVpositive parents reported a decline in school attendance and performance when parents became ill. The study also found that many parents had not taken key steps to inform and protect their children should they become ill and die, such as disclosing their HIV status, appointing a guardian, and writing a will [10, 11].

Horizons studies in several settings found that being female increased vulnerability. In South African communities highly affected by HIV, girls were more likely than boys to be out of school regardless of whether or not they had been orphaned [8]. Similarly, Horizons studies among vulnerable youth in Rwanda [12, 13], Zimbabwe (Table 2) [7], and South Africa [9] have shown girls are more likely than boys to report depression, traumatic life events, and low self-esteem, and to report their first sexual intercourse as unwilling. Women and girls also take on a disproportionate share of the burden of caring for orphans and vulnerable children in many settings, which can have negative repercussions for their own health and well-being $[14,15]$. A Horizons study conducted in eight districts in South Africa found that female-headed households were more likely than male-headed households to include orphans and vulnerable children $[8,16]$.

Age is also important when considering vulnerability. A Horizons study in Zimbabwe found that older youth had higher trauma scores and exhibited more signs of psychosocial distresssuch as feeling "alone in the world," hopeless, and worried-than their younger peers [7]. These results may reflect the challenges and responsibilities—such as unemployment and 
caring for younger siblingsthat befall many older youth.

In communities that are deeply affected by AIDS, care for orphans and vulnerable children often falls on the elderly, especially elderly women. In Kenya and South Africa, Horizons studies found that caring for OVC can compromise older caregivers' emotional well-being and encroach on time available for involvement in social and economic activities. Elderly caregivers in South Africa reported feeling they have little influence on the behavior of youth, sometimes expressing a sense of confusion and hopelessness [17]. Despite these burdens, many caregivers interviewed in Kenya and South Africa cited a sense of satisfaction in caring for ill adults and their young family members $[17,18]$.

Still, children may face significant hardships when raised by elderly caregivers. In Kenya, Horizons found that children who depend upon elderly caregivers often drop out of school and are expected to complete heavy workloads in the home. Also, some children may experience inadequate or inappropriate levels of discipline [18].

A significant number of children whose mothers are HIV-positive are themselves infected with the virus. While still limited, pediatric HIV testing and treatment services are increasingly becoming available to help these highly vulnerable children. Horizons studies conducted with partners in Kenya and South Africa have documented several obstacles that interfere with access to pediatric HIV care and treatment. These include limited community
Table 2 Sex differences among orphans and vulnerable children in psychosocial distress and well-being outcomes in Bulawayo, Zimbabwe

\begin{tabular}{lcc} 
& Males & Females \\
\hline Psychosocial distress ${ }^{*}$ & 60 & 69 \\
Felt irritable or bothered & 43 & 54 \\
Felt nothing in life interested them & 34 & 45 \\
Felt alone in the world & 33 & 42 \\
Spent a lot of time sleeping & 56 & 68 \\
Had headaches or stomachaches & 56 & 68 \\
Had no appetite & 38 & 53 \\
Felt sad & 59 & 66 \\
Cried & 44 & 64 \\
Had nightmares & 53 & 59 \\
Felt others are targeting them & 50 & 58 \\
Psychosocial well-being & \\
Feel confident in themselves & 83 & 74 \\
Feel hopeful about the future & 81 & 75 \\
Enjoy spending time with friends & 94 & 90 \\
\hline * Differences experienced sometimes or most of the time in the last month between males and females are \\
statistically significant $p<.05$ for each type of psychosocial distress and psychosocial well-being. \\
& & \\
\hline
\end{tabular}

awareness of the indications for HIV testing among children; parental fear that if their children test HIV-positive, their own HIV status will be publicly revealed; providers of home-based care not identifying potentially HIV-infected children or promoting testing; and feelings of fatalism and loss of hope among surviving parents and guardians [19,20].

\section{Pioneering Intervention Strategies}

These findings helped shape a number of intervention strategies that were developed and tested by Horizons and partners through opera- 
tions research. Data have shown that interventions for vulnerable children need to begin before parental death. Programs need to address the psychosocial needs of children, including adult support and clinical services. They need to provide caregivers with training, assistance, and emotional support, both family caregivers and community volunteers, and engage community members in decision-making to foster program ownership.

\section{Planning for children's futures}

In Uganda, Horizons researchers assessed a succession planning program that aimed to reduce uncertainty and fear among adults and children about the children's future well-being. The program provided counseling to HIV-positive parents on disclosure to children, support for appointing standby guardians, training in legal literacy and will writing, and training and seed money for income-generating activities. The study documented significant increases among parents in the appointment of guardians, a doubling in the number of wills written, and an increase in parents telling their children they have HIV. These results prompted international agencies and donors to acknowledge the importance of this approach and recommend expansion of the program $[10,11]$.

\section{Mentoring child-headed households}

Horizons research in Rwanda found that through regular home visits, trained adult volunteers developed a stable, caring relationship with children and youth living without an adult caregiver. High levels of depression, maltreatment, and marginalization were reported at baseline. Follow-up data two years later indicated greater positive psychosocial changes among young heads of households who had been supported by adult volunteers, compared to young heads of households not in contact with volunteers. Data showed that youth household heads perceived the greatest benefits when the mentors visited them and their siblings at least twice a month $[12,13]$.

\section{Training young people as volunteer caregivers}

Horizons studies in Zambia and South Africa demonstrated the feasibility and value of training young people to serve as volunteer caregivers within their communities. Although a program in Zambia initially aimed to train young people to help care for adults suffering from chronic illness, it became apparent that many of the young caregivers spent considerable time supporting children in these AIDS-affected households by providing counseling, help with homework and chores, and assistance in navigating health and education services. Young caregivers also reported that regular visits to these households helped decrease stigmatization of their HIV-infected clients by family and community members [21, 22]. In South Africa, young people trained as caregivers provided psychosocial support and HIV education to primary school students living in vulnerable settings. Horizons research showed that this program was associated with improved HIVrelated knowledge, more frequent communication about AIDS, and more accepting attitudes toward people infected and affected by HIV [23].

These studies also found that young caregivers reported gaining valuable skills and knowledge in first aid, counseling, and making contacts with healthcare facilities and schools [2123]. In Zambia, survey data show that condom use increased among sexually active young caregivers after participating in the program (Figure 
Figure 1 Condom use increased significantly among sexually active youth in northern Zambia who participated in the caregiver intervention

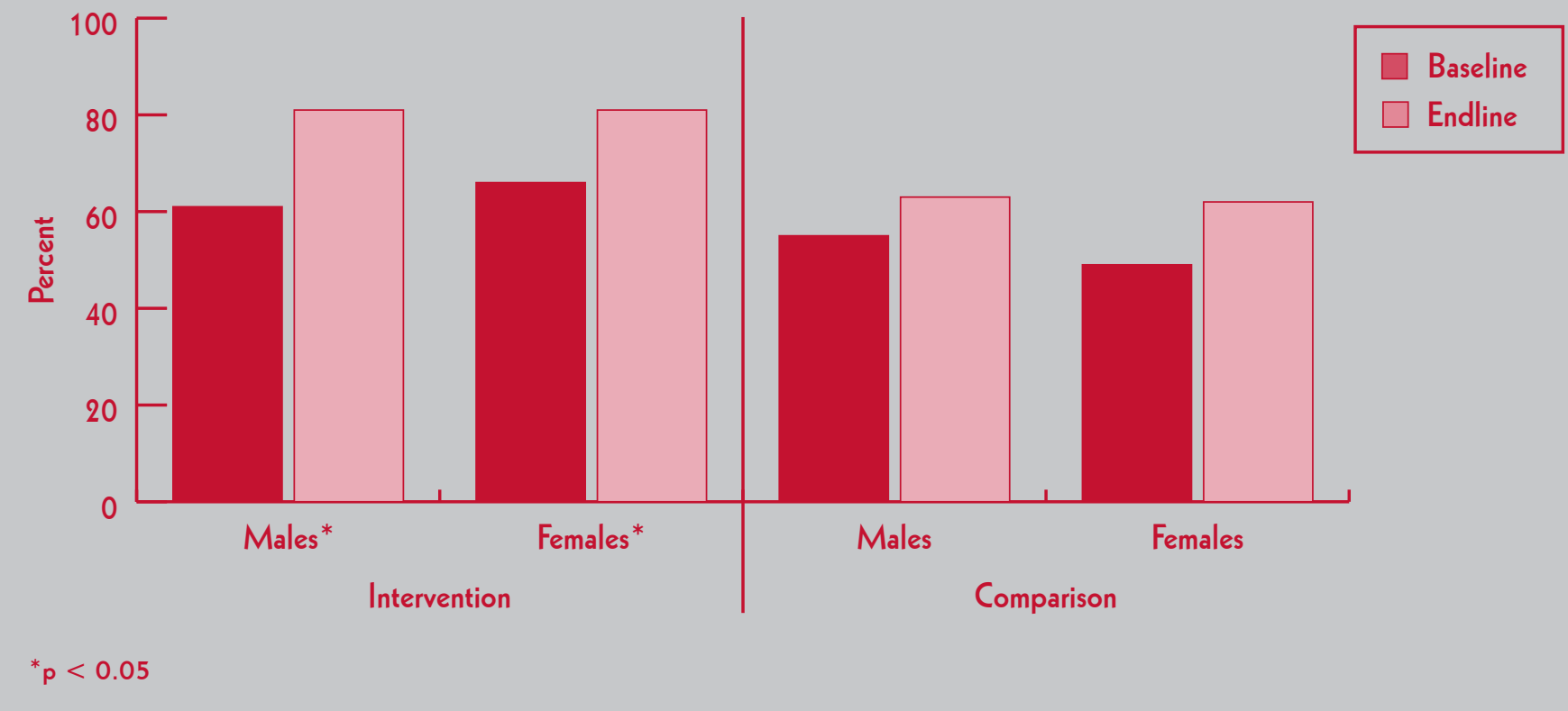

1) [22]. Qualitative data reveal that young caregivers gained satisfaction from serving their communities and earning respect from local leaders. Program staff and stakeholders reported that young people were easy to train as caregivers and were flexible about their availability and the type of household work they carried out, including domestic chores. Male caregivers showed a remarkable willingness to participate equally in caregiving activities traditionally carried out by females [21, 22].

\section{Addressing the needs of elderly caregivers}

Building on formative research in South Africa that described the substantial caregiving burden borne by the elderly [17], Horizons and partners piloted a community-based intervention to address the needs of elderly caregivers and barriers to providing high-quality care. The intervention consisted of a series of workshops on intergenerational communication, basic nursing care, how to gain access to social services and grants, and relaxation techniques. Study findings revealed that elderly caregivers who participated in the intervention experienced improved knowledge about HIV, increased self-esteem, less anxiety about the future, and reduced anger toward their dependents. Further, elderly caregivers reported gaining valuable new skills from the workshops, such as how to better communicate with young people [24].

\section{Linking children with community resources}

Horizons studies emphasized the importance of networking to link OVC programs with existing community resources and clinical services. In Zambia, partnerships with local health and social welfare institutions legitimized the efforts of young caregivers and extended the scope of activities beyond what they could have carried out alone [21,22]. Partners provided supplies, school fees and materials for their clients' children. Capacity-building activities developed the ability of young caregivers to generate resources. Partnerships with local community groups and institutions also provided crucial elements of support and reinforcement to other volunteer caregivers. For example, home-based care providers in Malawi sought communica- 
tion and collaboration with village health committees, church groups, and traditional healers [25], while similar programs in Zambia provided valuable mentoring and support to volunteer young caregivers [22]. In South Africa, elderly caregivers benefited from workshops conducted as a result of collaboration between health, social development, and community organizations [24].

Horizons' studies illustrate the importance of the participation of local community members and stakeholders at each step of program development and implementation, including community leaders, parents/guardians, and teachers. The mentorship program in Rwanda demonstrated that giving the volunteer adult

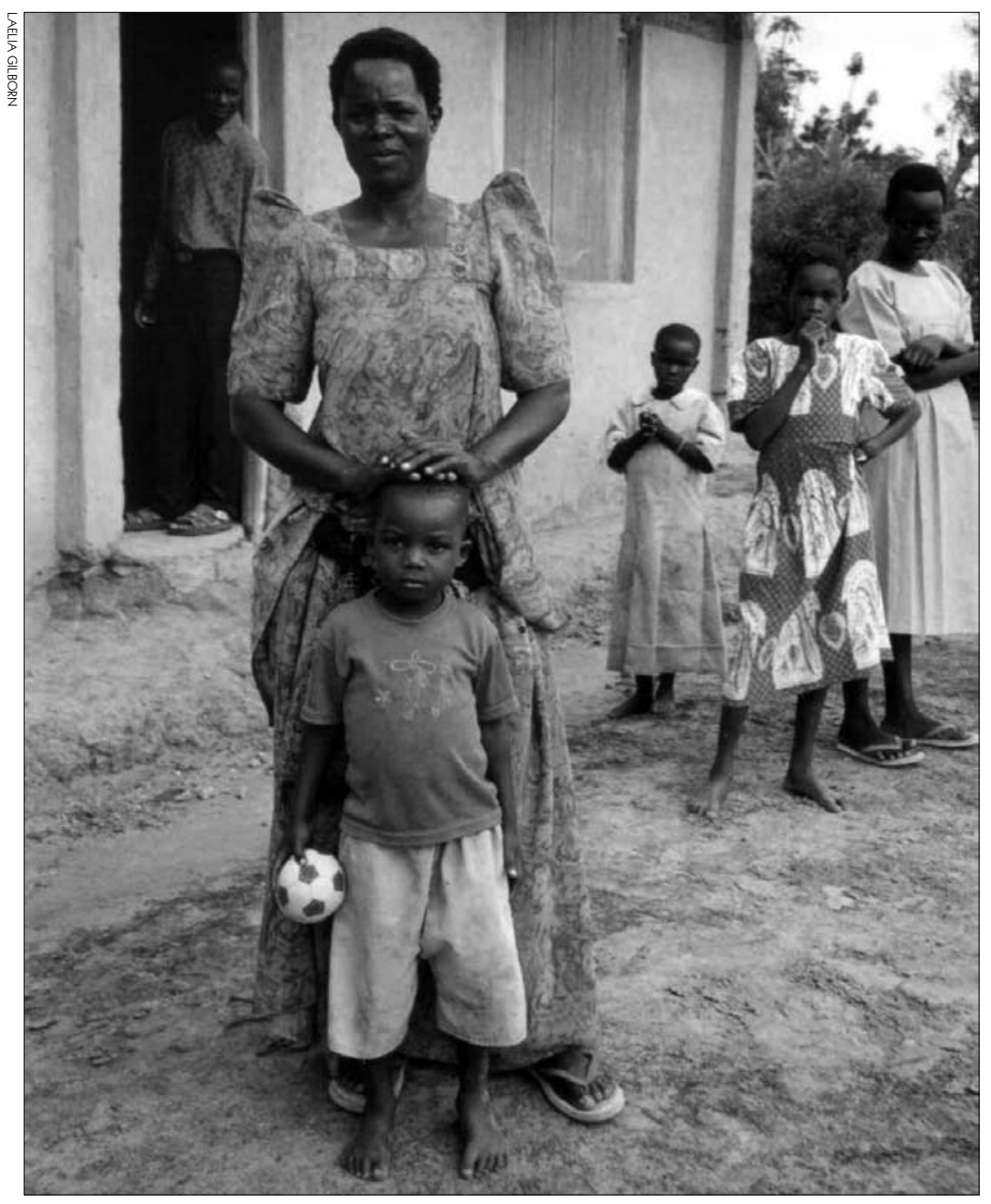

In communities that are deeply affected by AIDS, such as here in Uganda, care for orphans and vulnerable children often falls on the elderly, especially elderly women. mentors decision-making power to set direction for the program catalyzed broader community support for orphans and vulnerable children and helped sustain activities $[12,13]$.

\section{Supporting volunteer caregivers}

To reduce program costs and make the most of existing resources, many programs train volunteers as caregivers. Horizons' evaluation data support the value of this approach but also emphasize the importance of providing ongoing training, support, and incentives to motivate caregivers and sustain high-quality programs.

In Zambia and South Africa, trained young caregivers reported experiencing stress and emotional distress when caring for AIDSaffected children, particularly when confronted by family disputes, funeral arrangements, and food shortages $[21,22]$. These volunteers benefited from support provided to them by the programs and referrals to more comprehensive community services when needed. Training and ongoing support must prepare caregivers to best define their role, to be aware of limitations in what they can and cannot provide, and to be able to communicate this to their clients.

Lack of recognition and recompense for volunteer caregivers can be barriers to long-term program sustainability $[23,25,26]$. In South Africa, the attrition rate among volunteer young caregivers was high due to lack of financial reimbursement and transportation, and to "poaching" from competing NGOs [23]. But in Rwanda, very few adult mentors dropped out of the mentorship program for youthheaded households over an 18-month period. Program implementers found that factors contributing to these high volunteer retention rates included: involving volunteers in key program decisions, holding monthly support meetings, formally recognizing and appreciating the volunteers' work, and providing access to incomegenerating opportunities [12]. 


\section{Developing Ethical and Innovative Research Methods}

Horizons recognized that there were methodological and ethical gaps in conducting research on issues regarding orphans and vulnerable children. Through its work in sub-Saharan Africa, Horizons has contributed to the development of research measures and ethical guidelines that have helped the field better understand and measure the psychosocial dimensions of vulnerability, develop and test responses to improve psychosocial outcomes, and protect children while collecting data for these purposes.

\section{Measuring psychosocial well-being}

In Uganda and Zimbabwe, researchers developed, tested, and refined measures of psychosocial well-being $[7,11]$. This shaped later research in Rwanda that tested new measures of social support, grief, maltreatment, and mar- ginalization [13]. Box 1 shows items from the grief and marginalization scales that were part of the instrument used to examine the impact of an adult mentorship program on youthheaded households.

\section{Outlining ethical guidelines for research with children}

Recognizing the need for guidance in the conduct of social and behavioral research among children affected by HIV, Horizons spearheaded the development of a document [29] that highlights the responsibilities of research staff to ensure that such activities are conducted ethically with the utmost regard for children's health, well-being, and rights. This pioneering document identifies challenges confronting program implementers and investigators and proposes practical solutions [30]. Among topics covered by the publication are gaining meaningful informed consent from children and creating opportunities for children to partici-

\section{Box 1 Measuring psychosocial well-being}

Researchers in the Rwanda study developed and validated scales to measure psychosocial well-being among youth head of households, aged 13-24. Each item was scored on a 5-point scale from "strongly agree" to "strongly disagree". Below are examples of the statements used for the marginalization and grief scales [27, 28]:

Marginalization

- People in this community would rather hurt you than help you.

- You feel isolated from others in the community.

- No one cares about you.

- People make fun of your situation.

- People speak badly about you or your family.

- The community rejects orphans.

\section{Grief}

- You think about the death of your loved one(s) almost all the time.

- You feel angry when you think about the death(s).

- You still can't believe your loved one(s) is/are really dead (or gone).

- Your faith in God is shaken since the death of your loved one(s).

- Since the death of your loved one, you have lost confidence in people.

- Since the death of your loved one, life is meaningless. 


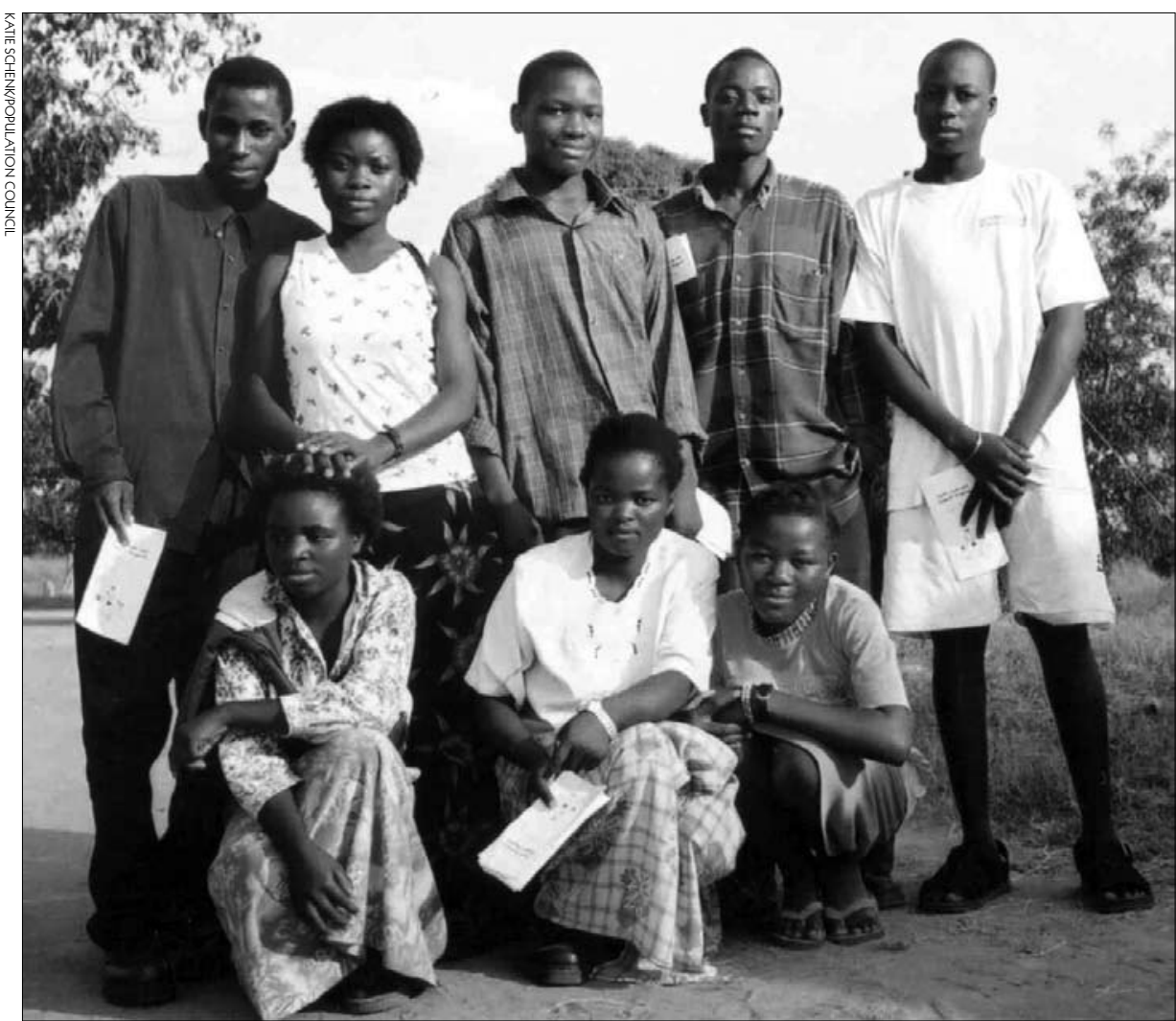

Horizons' evaluation data support the value of training youth as caregivers, such as these youth in Zambia, for AIDS-affected children, but also emphasize the importance of providing ongoing training, support, and incentives to motivate caregivers and sustain high-quality programs. are not only possible but yield rich findings and that quasi-experimental research designs and process evaluations provide valuable and scientifically valid frameworks for building the empirical data on OVC care and support programs.

Horizons' studies have documented a range of HIV-related impacts that critically affect the health and well-being of orphans and vulnerable children and demonstrated that programs can make tangible improvements to the lives of children and families affected by AIDS. Important findings highlight the value of adult support and guidance; the need to focus on the circumstances of girls, women, and the elderly; the importance of meeting ethical standards in research among children who are vulnerable; and the fundamental understanding of vulnerability as broader than orphanhood. They also underscore the potential of community members-including youth and adults - to be part of the solution to the problems facing AIDSaffected families. design, instrument development, and results interpretation.

\section{Moving Forward: Research and Program Priorities}

As Horizons ends a decade of research on orphans and vulnerable children, how will its pioneering efforts help shape and encourage future research and programs? Evidence from the Horizons OVC portfolio indicates that the practical and ethical challenges of conducting research among children in vulnerable circumstances are not insurmountable. Horizons demonstrated that diagnostic studies and sound evaluations of community-based interventions
While community-based psychosocial support programs and caregiving interventions_-such as the interventions evaluated by Horizons in Rwanda, Zimbabwe, Zambia, and South Africa-have proven beneficial to many participants, these programs may not be able to improve all aspects of all participants' health and well-being. Horizons' research indicates that future program priorities must include the development of functional links between care and support interventions for orphans and vulnerable children and other key services for young people, such as HIV prevention and life-skills education, health services, including access to antiretroviral treatment, and livelihood support. 
A focus on links, referrals, and, where appropriate, program integration can help service providers meet the many and diverse needs of vulnerable young people while safeguarding their rights. It may also contribute to greater program coverage and efficiency. Additionally, proactive engagement with community members, networking and capacity-building of local organizations, and systematic priority setting are key to long-term program sustainability.

Yet important work remains. The evaluation of community-based OVC interventions continues to be a key gap in the evidence base. Developing and scaling up appropriate interventions requires research guided by the input of

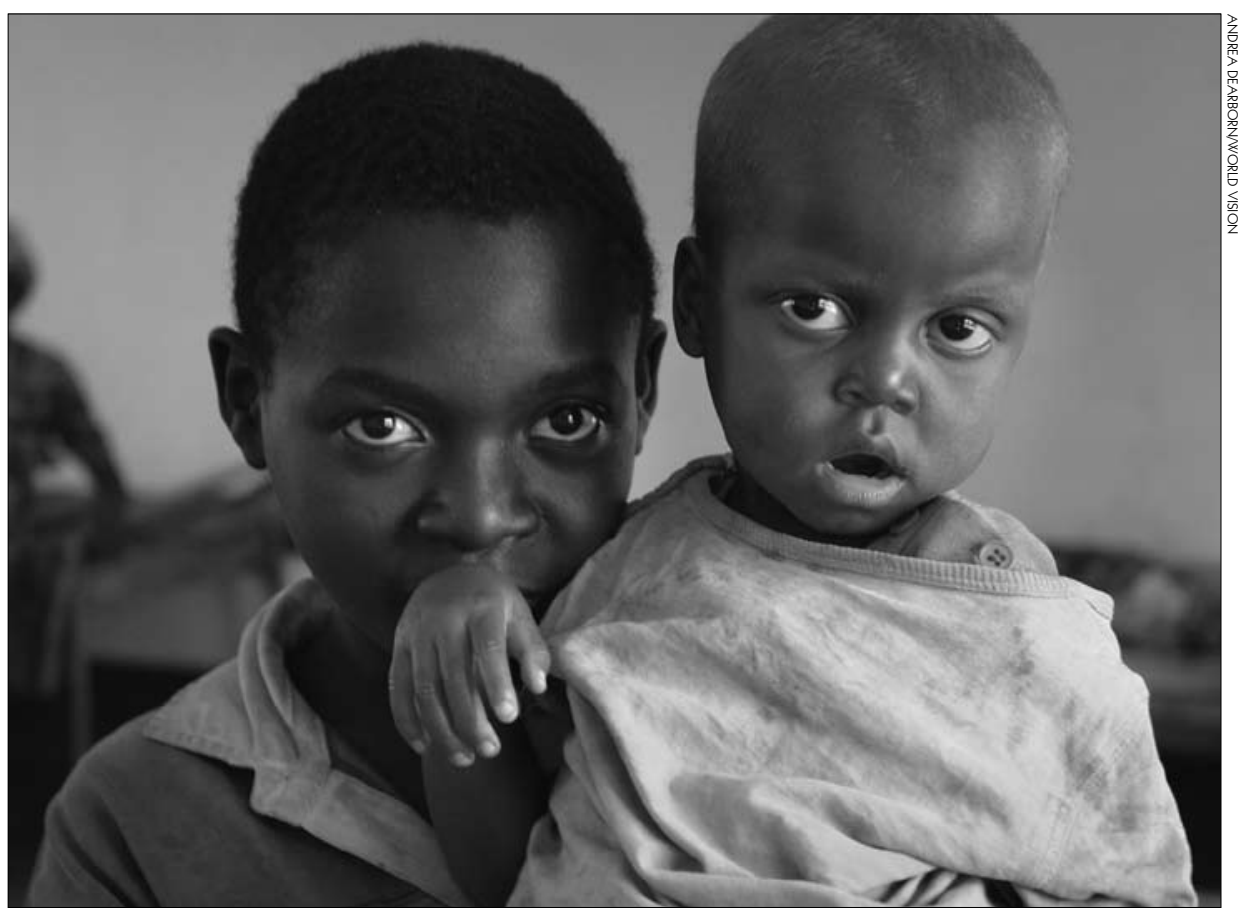

Horizons' research indicates that future program priorities must include the development of functional links between care and support interventions for orphans and vulnerable children and other key services for young people. community members and stakeholders to ensure that programs are achieving their desired goals without harming children or jeopardizing their rights. The resulting data will enable program implementers, policymakers, and donors to decide which strategies are most effective and how they should be implemented. While investment in rigorous evaluation is initially resource intensive, the long-term payoff of developing a solid evidence base will ensure that future spending is directed at producing better outcomes for more children. 


\section{APPENDIX}

\section{Summary of Horizons OVC research portfolio}

\begin{tabular}{|c|c|c|c|c|}
\hline Study title and country & Dates & Horizons' partners & Study design & Sample \\
\hline \multicolumn{5}{|c|}{ DIAGNOSING THE PROBLEM } \\
\hline $\begin{array}{l}\text { "Our hearts are willing, } \\
\text { but. ." Challenges of } \\
\text { elderly caregivers in rural } \\
\text { Kenya } \\
{[18]}\end{array}$ & 2003 & Plan International Kenya & $\begin{array}{l}\text { Community-based qualitative } \\
\text { study. }\end{array}$ & $\begin{array}{l}\text { Focus group discussions } \\
\text { (FGDs) and in-depth } \\
\text { interviews (IDIs) with } \\
\text { community leaders and } \\
\text { elderly caregivers. }\end{array}$ \\
\hline $\begin{array}{l}\text { Challenges faced by } \\
\text { households in caring for } \\
\text { orphans and vulnerable } \\
\text { children, South Africa } \\
{[8,16]}\end{array}$ & $\begin{array}{l}2001- \\
2002\end{array}$ & $\begin{array}{l}\text { Nelson Mandela } \\
\text { Children's Fund; } \\
\text { Development Research } \\
\text { Africa; FRONTIERS }\end{array}$ & $\begin{array}{l}\text { Household survey using a cluster } \\
\text { random sample research design. }\end{array}$ & $\begin{array}{l}4,966 \text { interviews with } \\
\text { household heads, } 2,541 \\
\text { male youth (12-22 years } \\
\text { old) and 2,539 female } \\
\text { youth. }\end{array}$ \\
\hline $\begin{array}{l}\text { "If you build it, will they } \\
\text { come?" Kenya Healthy Start } \\
\text { Pediatric HIV study: A } \\
\text { diagnostic study investigating } \\
\text { barriers to HIV treatment } \\
\text { and care among children } \\
\text { [20] }\end{array}$ & 2007 & $\begin{array}{l}\text { Elizabeth Glaser Pediatric } \\
\text { HIV/AIDS Foundation; } \\
\text { Diocese of Nairobi } \\
\text { Eastern Deanery AIDS } \\
\text { Relief Program; Kenya } \\
\text { Network of Women with } \\
\text { AIDS; Christian Health } \\
\text { Association of Kenya }\end{array}$ & $\begin{array}{l}\text { Qualitative and quantitative data } \\
\text { collected through a community- } \\
\text { based household survey of } \\
\text { caregivers and a mini-survey of } \\
\text { health workers. }\end{array}$ & $\begin{array}{l}\text { FGDs and IDIs with } \\
\text { health care providers, district } \\
\text { health management staff, } \\
\text { community health workers, } \\
\text { and members of PLHA } \\
\text { support groups. 1,180 } \\
\text { households and } 97 \text { health } \\
\text { workers surveyed. }\end{array}$ \\
\hline $\begin{array}{l}\text { Transitions to adulthood } \\
\text { in the context of AIDS in } \\
\text { KZN South Africa } \\
\text { [9] }\end{array}$ & 2001 & $\begin{array}{l}\text { Tulane School of Public } \\
\text { Health and Tropical } \\
\text { Medicine; University of } \\
\text { KwaZulu-Natal; Family } \\
\text { Health International }\end{array}$ & $\begin{array}{l}\text { Secondary data analysis of survey } \\
\text { data from a youth panel study. }\end{array}$ & 1,694 youth aged $14-18$. \\
\hline $\begin{array}{l}\text { Factors affecting access to } \\
\text { ART and HIV care services } \\
\text { for OVC: A situation } \\
\text { analysis in the Mariannhill } \\
\text { area of KwaZulu-Natal } \\
\text { [19] }\end{array}$ & 2007 & $\begin{array}{l}\text { Medical Research Council; } \\
\text { St Mary's Hospital }\end{array}$ & $\begin{array}{l}\text { Diagnostic study. } \\
\text { Mini-surveys and FGDs/IDls } \\
\text { among health service providers } \\
\text { and caregivers for orphans and } \\
\text { vulnerable children from the } \\
\text { Mariannhill communities. } \\
\text { FGDs/IDls among community } \\
\text { health workers and staff of local } \\
\text { orphanages and institutions caring } \\
\text { for OVC. }\end{array}$ & \\
\hline
\end{tabular}




\begin{tabular}{|c|c|c|c|c|c|}
\hline $\begin{array}{l}\text { Study Title and } \\
\text { Country }\end{array}$ & Dates & Horizons' Partners & Intervention & Study Design & Sample \\
\hline \multicolumn{6}{|c|}{ USING PIONEERING INTERVENTION STRATEGIES } \\
\hline $\begin{array}{l}\text { Assessment of the } \\
\text { community-based } \\
\text { options for protection } \\
\text { and empowerment } \\
\text { program, Namwera, } \\
\text { Malawi } \\
\text { [25] }\end{array}$ & $\begin{array}{l}1998- \\
1999\end{array}$ & $\begin{array}{l}\text { Save the Children US- } \\
\text { Malawi }\end{array}$ & $\begin{array}{l}\text { Village committees } \\
\text { formed to catalyze } \\
\text { community-based } \\
\text { HIV prevention and } \\
\text { care activities. }\end{array}$ & $\begin{array}{l}\text { Retrospective, qualitative } \\
\text { evaluation including FGDs } \\
\text { and IDIs. }\end{array}$ & $\begin{array}{l}\text { Representatives } \\
\text { from } 10 \\
\text { participating and } 3 \\
\text { non-participating } \\
\text { villages, including } \\
\text { youth, caregivers, } \\
\text { teachers, } \\
\text { religious leaders, } \\
\text { village heads, } \\
\text { and committee } \\
\text { members. }\end{array}$ \\
\hline $\begin{array}{l}\text { Succession planning in } \\
\text { Uganda: Early outreach } \\
\text { for AIDS-affected } \\
\text { children and their } \\
\text { families } \\
{[10,11,31]}\end{array}$ & $\begin{array}{l}1999- \\
2002\end{array}$ & $\begin{array}{l}\text { Makerere University, } \\
\text { Department of } \\
\text { Sociology; Plan Uganda }\end{array}$ & $\begin{array}{l}\text { Counseling to } \\
\text { help HIV-positive } \\
\text { parents disclose to } \\
\text { their children and } \\
\text { appoint guardians, } \\
\text { training on will } \\
\text { writing, provision } \\
\text { of school fees and } \\
\text { vocational training, } \\
\text { training for standby } \\
\text { guardians. }\end{array}$ & $\begin{array}{l}\text { Quasi-experimental study } \\
\text { with intervention and } \\
\text { comparison arms. }\end{array}$ & $\begin{array}{l}\text { Cross-sectional } \\
\text { samples of } 1,270 \\
\text { HIV-positive } \\
\text { parents, } 80 \\
\text { suardians, and } 140 \\
\text { children of HIV- } \\
\text { positive parents } \\
\text { aged } 13-19 \text { years. }\end{array}$ \\
\hline $\begin{array}{l}\text { Orphans and } \\
\text { vulnerable youth in } \\
\text { Bulawayo, Zimbabwe: } \\
\text { An exploratory study } \\
\text { of psychosocial well- } \\
\text { being and psychosocial } \\
\text { support programs } \\
\text { [7] }\end{array}$ & $\begin{array}{l}2003- \\
2004\end{array}$ & $\begin{array}{l}\text { Regional Psychosocial } \\
\text { Support Initiative } \\
\text { (REPSSI); Catholic } \\
\text { Relief Services-STRIVE } \\
\text { Program; Salvation Army } \\
\text { Masiye Camp }\end{array}$ & $\begin{array}{l}\text { Community } \\
\text { psychosocial } \\
\text { support programs, } \\
\text { including Kids' } \\
\text { Clubs, a residential } \\
\text { camp, and peer } \\
\text { leader training. }\end{array}$ & $\begin{array}{l}\text { Qualitative research } \\
\text { followed by a survey. }\end{array}$ & $\begin{array}{l}\text { Cross-sectional } \\
\text { sample of } 1,258 \\
\text { vulnerable youth, } \\
\text { including those } \\
\text { who had and had } \\
\text { not participated } \\
\text { in psychosocial } \\
\text { support programs. }\end{array}$ \\
\hline $\begin{array}{l}\text { Assessing the } \\
\text { psychosocial benefits } \\
\text { of a community-based } \\
\text { mentoring program } \\
\text { for youth-headed } \\
\text { households in Rwanda } \\
{[6,12,13,27 \text {, }} \\
32-34]\end{array}$ & $\begin{array}{l}2004- \\
2006\end{array}$ & $\begin{array}{l}\text { World Vision Rwanda; } \\
\text { Rwanda School of Public } \\
\text { Health; Tulane University }\end{array}$ & $\begin{array}{l}\text { Adult volunteer } \\
\text { mentors trained to } \\
\text { provide guidance } \\
\text { and support to } \\
\text { children and youth } \\
\text { living without an } \\
\text { adult caregiver. }\end{array}$ & $\begin{array}{l}\text { Quasi-experimental study } \\
\text { with intervention and } \\
\text { comparison groups. }\end{array}$ & $\begin{array}{l}\text { Cross-sectional } \\
\text { samples of } 692 \\
\text { youth heads of } \\
\text { household at } \\
\text { baseline and } 593 \\
\text { at follow-up. }\end{array}$ \\
\hline $\begin{array}{l}\text { A pilot community- } \\
\text { based intervention } \\
\text { program to address } \\
\text { the needs of elderly } \\
\text { caregivers in the } \\
\text { Eastern Cape Province, } \\
\text { South Africa } \\
{[17,24]}\end{array}$ & $\begin{array}{l}2006- \\
2007\end{array}$ & $\begin{array}{l}\text { Medical Research } \\
\text { Council }\end{array}$ & $\begin{array}{l}\text { Four workshops } \\
\text { focusing on HIV, } \\
\text { intergenerational } \\
\text { communication, } \\
\text { home-based care, } \\
\text { social services } \\
\text { and grants, } \\
\text { and relaxation } \\
\text { techniques. }\end{array}$ & $\begin{array}{l}\text { Quasi-experimental study } \\
\text { with intervention and } \\
\text { comparison groups. }\end{array}$ & $\begin{array}{l}\text { Cross-sectional } \\
\text { sample of } 409 \\
\text { elderly caregivers } \\
\text { at baseline, } 366 \\
\text { immediately after } \\
\text { the intervention, } \\
\text { and } 363 \text { three } \\
\text { months later. }\end{array}$ \\
\hline
\end{tabular}




\begin{tabular}{|l|l|l|l|l|l|}
\hline $\begin{array}{l}\text { Involving young people } \\
\text { in the care and support } \\
\text { of people living with } \\
\text { HIV/AIDS in Zambia } \\
{[21,22,26,35]}\end{array}$ & $2000-$ & $\begin{array}{l}\text { CARE Zambia; Family } \\
\text { Health Trust }\end{array}$ & $\begin{array}{l}\text { Anti-AIDS clubs } \\
\text { train youth to } \\
\text { provide care and } \\
\text { support to people } \\
\text { living with HIV. } \\
\text { Clubs also supplied } \\
\text { with care kits and } \\
\text { bicycles. }\end{array}$ & $\begin{array}{l}\text { Quasi-experimental study } \\
\text { with intervention and } \\
\text { comparison arms. }\end{array}$ & $\begin{array}{l}\text { Cross-sectional } \\
\text { sample of 796 } \\
\text { youth at baseline } \\
\text { and 983 at follow- } \\
\text { up. }\end{array}$ \\
\hline $\begin{array}{l}\text { Training youth } \\
\text { caregivers to provide } \\
\text { HIV education and } \\
\text { support to orphans and } \\
\text { vulnerable children in } \\
\begin{array}{l}\text { South Africa } \\
\text { [23] }\end{array}\end{array}$ & 2006 & $\begin{array}{l}\text { The Valley Trust } \\
\text { youth trained } \\
\text { to provide HIV } \\
\text { education, } \\
\text { homework } \\
\text { assistance, and } \\
\text { psychosocial } \\
\text { support to OVC } \\
\text { aged 11-15 years. }\end{array}$ & Pre-post test design. & $\begin{array}{l}\text { Cross-sectional } \\
\text { samples of 597 } \\
\text { students at baseline } \\
\text { and 524 at follow- } \\
\text { up. FGD with 48 } \\
\text { participants. }\end{array}$ \\
\end{tabular}


1. S. S. Hunter, "Orphans as a window on the AIDS epidemic in Sub-Saharan Africa: initial results and implications of a study in Uganda," Social Science and Medicine 31 (6): 681-90 (1990).

2. E. A. Preble, "Impact of HIV/AIDS on African children," Social Science and Medicine 31 (6): 671-80 (1990).

3. S. Hunter, J. Williamson, Children on the Brink: Strategies to Support Children Isolated by HIVI AIDS (Washington, D.C.: USAID, 1997).

4. A. Dunn, E. Jareg, D. Webb, A Last Resort: The Growing Concern about Children in Residential Care (London: International Save the Children Alliance, undated).

5. G. Foster et al., "Orphan prevalence and extended family care in a peri-urban community in Zimbabwe," AIDS Care 7 (1): 3-17 (1995).

6. L. Brown, T. R. Thurman, L. Snider, "Strengthening the psychosocial well-being of youth-headed households in Rwanda: Baseline findings from an intervention trial," Horizons Research Update (Washington, D.C.: Population Council, 2005).

7. L. Z. Gilborn et al., "Orphans and vulnerable youth in Bulawayo, Zimbabwe: An exploratory study of psychosocial well-being and psychosocial support programs," Horizons Final Report (Washington, D.C.: Population Council, 2006).

8. K. Vermaak et al., Vulnerability and intervention opportunities: Research findings on youth and HIV/AIDS in South Africa," Horizons Research Update (Washington, D.C.: Population Council, 2004).

9. T. R. Thurman et al., "Sexual risk behavior among South African adolescents: is orphan status a factor?," AIDS Behavior 10 (6): 627-35 (2006).

10. Horizons Program, "Succession planning in Uganda: Early outreach for AIDS-affected children and their families," Horizons Research Summary (Washington, D.C.: Population Council, 2003).
11. Horizons, Makerere University, and Plan/Uganda, "Succession planning in Uganda: Early outreach for AIDS-affected children and their families," Horizons Final Report (Washington, D.C.: Population Council, 2004).

12. L. Brown et al., "Supporting volunteer mentors: Insights from a mentorship program for youthheaded households in Rwanda," Horizons Research Summary (Washington, D.C.: Population Council, 2007).

13. L. Brown et al., "Psychosocial benefits of a mentoring program for youth-headed households in Rwanda," Horizons Research Summary (Washington, D.C.: Population Council, 2007).

14. J. Ogden, S. Esim, C. Grown, "Expanding the care continuum for HIV/AIDS: Bringing carers into focus," Horizons Final Report (Washington, D.C.: Population Council and International Center for Research on Women, 2004).

15. J. Ogden, S. Esim, C. Grown, "Expanding the care continuum for HIV/AIDS: Bringing carers into focus," Health Policy and Planning 21 (5): 333-342 (2006).

16. K. Vermaak et al., "Challenges faced by households in caring for orphans and vulnerable children," Horizons Research Update (Washington, D.C.: Population Council, 2004).

17. P. Reddy et al., "Inkala ixinge etyeni: Trapped in a difficult situation': The burden of care on the elderly in the Eastern Cape, South Africa," Horizons Research Update (Johannesburg: Population Council, 2005).

18. M. Juma, T. Okeyo, G. Kidenda, “'Our hearts are willing, but...' Challenges of elderly caregivers in rural Kenya," Horizons Research Update (Nairobi: Population Council, 2004).

19. P. Reddy, S. James, "Factors affecting access to ART and HIV care services for OVC: A situation analysis in the Mariannhill area of KZN, South Africa," unpublished, Population Council: Washington, DC. 
20. K. Kiragu et al., "If you build it, will they come?" Kenya HealthyStart Pediatric HIV Study-A diagnostic study investigating barriers to HIV treatment and care among children," Horizons Final Report (Washington, D.C.: Population Council, 2008).

21. E. Esu-Williams et al., "We are no longer called club members but caregivers': Involving youth in HIV and AIDS caregiving in rural Zambia," AIDS Care 18 (8): 888-894 (2006).

22. E. Esu-Williams et al., "Involving young people in the care and support of people living with HIV and AIDS in Zambia," Horizons Final Report (Washington, D.C.: Population Council, 2004).

23. T. Nelson et al., "Training youth caregivers to provide HIV education and support to orphans and vulnerable children in South Africa," Horizons Research Summary (Washington, D.C.: Population Council, 2008).

24. P. Reddy et al., "Pilot community-based intervention to address the needs of elderly caregivers in the Eastern Cape Province, South Africa," Horizons Research Summary. (Washington, D.C.: Population Council, 2009).

25. E. Esu-Williams et al., "A retrospective assessment of the COPE 1 Program in Namwera, Malawi," Horizons Final Report (Washington, D.C.: Population Council, 2000).

26. E. Esu-Williams et al., "Involving young people in the care and support of people living with HIV in Zambia: An evaluation of program sustainability," Horizons Research Summary (Washington, D.C.: Population Council, 2008).

27. T. R. Thurman et al., "Psychosocial support and marginalization of youth-headed households in Rwanda," AIDS Care 18 (3): 220-229 (2006).

28. L. Brown et al., "Impact of a mentoring program on psychosocial well-being of youth-headed households in Rwanda," Journal of Adolescent Health [under review].

29. K. D. Schenk, J. Williamson, Ethical Approaches to Gathering Information among Children and Adolescents in International Settings: Guidelines and Resources (Washington, D.C.: Population Council, 2005).

30. K. D. Schenk, T. Murove, J. Williamson, "Protecting children's rights in the collection of health and welfare data," Health and Human Rights 9 (1): 80-100 (2006).

31. L. Z. Gilborn, R. Nyonyintono, R. Kabumbuli, G. Jagwe-Wadda, "Making a difference for children affected by AIDS: Baseline findings from Operations Research in Uganda," Horizons Baseline Report (Washington, D.C.: Population Council, 2001).
32. N. W. Boris et al., "Infants and young children living in youth-headed households in Rwanda: Implications of emerging data," Infant Mental Health Journal 27 (6): p. 584-602.

33. N. W. Boris et al., "Depressive symptoms in youth heads of household in Rwanda: Correlates and implications for intervention," Archives of Pediatric Medicine 162 (9): 836-843 (2008).

34. T. R. Thurman et al., "Barriers to the community support of orphans and vulnerable youth in Rwanda," Social Science \& Medicine 66 (7): 1557 1567 (2008).

35. E. Esu-Williams et al., "Involving youth in the care and support of people affected by HIV and AIDS," Horizons Research Summary (Washington, D.C.: Population Council, 2003). 


\section{ACKNOWLEDGMENTS}

The Horizons research studies reviewed in this synthesis were conducted in collaboration with local implementing and research partners, whose cooperation and input were vital. Special thanks are extended to Age-In-Action (South Africa), CARE (Zambia), Catholic Archdiocese of Ndola (Zambia), Catholic Diocese of Mansa (Zambia), Catholic Relief Services/STRIVE Program (Zimbabwe), Diocese of Luwero (Uganda), Family Health Trust (Zambia), Grasslands (Uganda), Makerere University (Uganda), Medical Research Council (South Africa), National Community of Women Living with AIDS (Uganda), Nelson Mandela Children's Fund/Goelama Project (South Africa), Plan International (Kenya and Uganda), Regional Psychosocial Support Initiative (Zimbabwe), Rwanda School of Public Health, Salvation Army/Masiye Camp (Zimbabwe), Save the Children (Malawi), and World Vision (Rwanda). Thanks also to the following people for their constructive contributions: Laelia Gilborn, LeeAnn Jones, Scott Kellerman, Hena Khan, Naomi Rutenberg, Tonya Thurman. Thanks to Gina Duclayan and Deborah Weiss for editing and Sherry Hutchinson for layout. 
Authors: Katie D. Schenk, Horizons/Population Council; Annie Michaelis, Horizons/Population Council; Tobey Nelson, Horizons/International Center for Research on Women; Lisanne Brown, Horizons/ Tulane University; and Ellen Weiss, Horizons/International Center for Research on Women
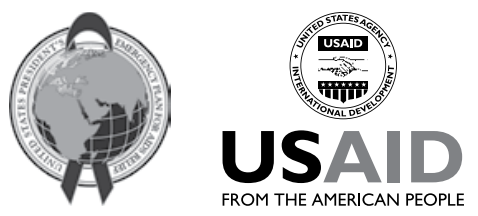

The studies and this paper were made possible by the President's Emergency Plan for AIDS Relief and the generous support of the American people through the United States Agency for International Development (USAID) under the terms of Cooperative Agreement No. HRNA-00-97-00012-00. The contents are the responsibility of the Horizons Program and do not necessarily reflect the views of USAID or the United States Government.

Published in April 2010.

\section{Q Population Council}

The Population Council is an international, non-profit, nongovernmental institution that seeks to improve the well-being and reproductive health of current and future generations around the world and to help achieve a humane, equitable, and sustainable balance between people and resources. The Council conducts biomedical, social science, and public health research and helps build research capacities in developing countries. Established in 1952, the Council is governed by an international board of trustees. Its New York headquarters supports a global network of regional and country offices.

Copyright (C) 2010. The Population Council Inc.

Suggested citation: Schenk, Katie D., Annie Michaelis, Tobey Nelson, Lisanne Brown, and Ellen Weiss. 2010. "Looking back, moving forward: Improving the lives of orphans and other children affected by AIDS, Horizons studies 1998 to 2007," Horizons Synthesis Background Papers. Washington, DC: Population Council.

This document may be reproduced in whole or in part without permission of the Population Council provided full source citation is given and the reproduction is not for commercial purposes. 


USAID

Population Council

HIV and AIDS Program

4301 Connecticut Ave NW, Suite 280

Washington, DC 20008

Tel: 202-237-9400

Fax: 202-237-8410

pubinfo@popcouncil.org 